\title{
Cardiac tamponade from appendiceal adenocarcinoma
}

\author{
Michael Omar 자, ${ }^{1}$ William Kogler, ${ }^{1}$ Kimberly Sanders, ${ }^{1}$ Aaron Richardson (i] ${ }^{2}$
}

${ }^{1}$ Internal Medicine, University of Florida College of Medicine, Jacksonville, Florida, USA ${ }^{2}$ Cardiology, University of Florida Health Science Center Jacksonville, Jacksonville, Florida, USA

\section{Correspondence to}

Dr Michael Omar;

michael.omar@jax.ufl.edu

Accepted 27 June 2020
Check for updates

(C) BMJ Publishing Group Limited 2020. No commercial re-use. See rights and permissions. Published by BMJ.

To cite: Omar M, Kogler W, Sanders K, et al. BMJ Case Rep 2020;13:e235878. doi: $10.1136 /$ bcr-2020 235878

\section{DESCRIPTION}

A 69-year-old woman presented with worsening dyspnoea for a month. She had a history of moderately differentiated non-mucinous appendiceal adenocarcinoma, diagnosed 10 months prior based on pathology from an emergent appendectomy for acute appendicitis. Mesenteric margins had been indeterminate but the patient had been lost to follow-up. On this presentation, echocardiography revealed a large pericardial effusion with tamponade physiology (figure 1A). Emergent pericardial window was successfully performed. Pericardial fluid cytology and tissue histology with immunostaining were consistent with metastatic adenocarcinoma (figure 1B). Investigations for an alternative primary were unremarkable including mammography and CT imaging of the chest, abdomen and pelvis. The patient was referred to oncology for further management.

Appendiceal neoplasms can be broadly sorted into non-epithelial or epithelial tumours. Adenocarcinoma is a subset of the latter that accounts for less than $1 \%$ of all gastrointestinal neoplasms. ${ }^{1}$ The diagnosis is usually incidental, discovered on up to $1.4 \%$ of appendectomy specimens post appendicitis. ${ }^{1}$

Uniquely, mucin-secreting adenocarcinomas may parade as pseudomyxoma peritonei. Otherwise, extra-appendiceal manifestations may be seen as local colonic invasion or intra-abdominal lymph node spread. There are few reports of liver, lung and genitourinary metastases and a single case of thyroid metastasis. ${ }^{12}$

The rarity of appendiceal adenocarcinoma translates to a paucity of high-quality evidence for management strategies. Most experts recommend right hemicolectomy. ${ }^{13}$ Conversely, there are observational studies supporting solely appendectomy in cases with well-differentiated tumours confined to the appendix, without extension to

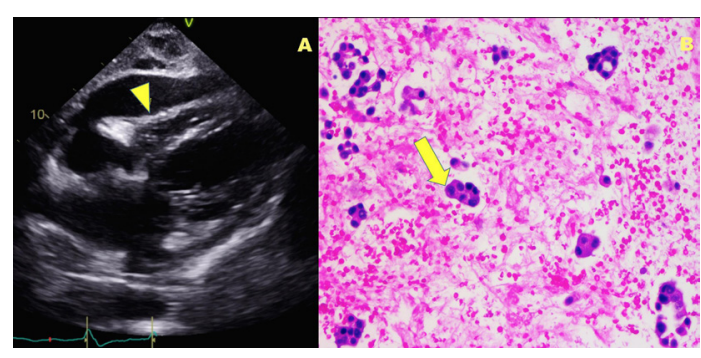

Figure 1 (A) Transthoracic echocardiography showing a pericardial effusion causing invagination of the right ventricle during diastole (arrowhead) and (B) pericardial histology showing adenocarcinoma cells (arrow).

\section{Patient's perspective}

I just thought I was okay after they took out the appendix, I did not know I had to come back. I feel okay now but I do not think I want to do anything else, I do not want chemotherapy or anything that will make me weaker.

\section{Learning points}

- Appendiceal adenocarcinoma has the potential to metastasise widely, even to the pericardium.

- If discovered, even incidentally on postoperative appendicitis specimen, it should prompt thorough staging and be treated aggressively with consideration for early haemicolectomy.

- Even though there may be distant metastases of appendiceal adenocarcinoma, some forms of chemotherapy may still be beneficial.

the base, smaller than $2 \mathrm{~cm}$ and without evidence of mesoappendiceal involvement. ${ }^{4}$ Cytoreductive surgery and heated intraperitoneal chemotherapy have proven beneficial, albeit in a highly selective group of patients with peritoneal involvement, thus precluding consensus on its role at this time. Furthermore, there are promising data with systemic chemotherapy, usually combination fluorouracil and platinum-based regimens, that demonstrate improved overall survivability even in patients with metastatic disease. ${ }^{56}$

Acknowledgements Thank you to Dr Jaime Morel Ruiz, MD, who assisted with obtaining our pathology images.

Contributors $\mathrm{MO}$ was responsible for writing and preparing the manuscript; KS was responsible for acquiring and preparing the figure; AR was responsible for final review and editing of the manuscript. WK was responsible for literature review and response to reviewer comments.

Funding The authors have not declared a specific grant for this research from any funding agency in the public, commercial or not-for-profit sectors.

Competing interests None declared.

Patient consent for publication Obtained.

Provenance and peer review Not commissioned; externally peer reviewed.

\section{ORCID iDs}

Michael Omar http://orcid.org/0000-0002-5777-386X

Aaron Richardson http://orcid.org/0000-0002-3786-4385 
Images in...

\section{REFERENCES}

1 Guraya SY, Almaramhy HH. Clinicopathological features and the outcome of surgical management for adenocarcinoma of the appendix. World J Gastrointest Surg 2011;3:7-12

2 Sharma SP, Attas LM. Metastatic appendiceal carcinoma diagnosed in an asymptomatic patient with incidental thyroid mass on routine examination. Gastrointest Cancer Res 2013;6:64-7.

3 McGory ML, Maggard MA, Kang H, et al. Malignancies of the appendix: beyond case series reports. Dis Colon Rectum 2005;48:2264-71.
4 Turaga KK, Pappas S, Gamblin TC. Right hemicolectomy for mucinous adenocarcinoma of the appendix: just right or too much? Ann Surg Oncol 2013;20:1063-7.

5 Lieu CH, Lambert LA, Wolff RA, et al. Systemic chemotherapy and surgical cytoreduction for poorly differentiated and signet ring cell adenocarcinomas of the appendix. Ann Oncol 2012;23:652-8.

6 Asare EA, Compton CC, Hanna NN, et al. The impact of stage, grade, and mucinous histology on the efficacy of systemic chemotherapy in adenocarcinomas of the appendix: analysis of the National cancer data base. Cancer 2016;122:213-21.

Copyright 2020 BMJ Publishing Group. All rights reserved. For permission to reuse any of this content visit https://www.bmj.com/company/products-services/rights-and-licensing/permissions/

BMJ Case Report Fellows may re-use this article for personal use and teaching without any further permission.

Become a Fellow of BMJ Case Reports today and you can:

- Submit as many cases as you like

- Enjoy fast sympathetic peer review and rapid publication of accepted articles

- Access all the published articles

- Re-use any of the published material for personal use and teaching without further permission

Customer Service

If you have any further queries about your subscription, please contact our customer services team on +44 (0) 2071111105 or via email at support@bmj.com.

Visit casereports.bmj.com for more articles like this and to become a Fellow 